\title{
GOLPES DE ESTADO: A PERSPECTIVA DA HISTÓRIA E A HISTÓRIA EM PERSPECTIVA
}

Prof. Dr. Alexandre Santos de Moraes ${ }^{1}$

No famoso lógos epitáphios de Péricles, entusiasticamente codificado por Tucídides, há um amálgama de elogio aos mortos e celebração da democracia. Na verdade, uma relação de intensa solidariedade ampara essa dupla disposição: nos discursos que fez a respeito de si, a pólis dos atenienses justificava reconhecer o valor dos mortos por ser democrática, e só era democrática por ter cidadãos tão valorosos como aqueles que primeiro tombaram na Guerra do Peloponeso. Em certo sentido, vigorava a certeza de que a cidade deveria ser objeto do cuidado coletivo. Foi para expressar esse cuidado que, no inverno de 431 a.C., Péricles foi convidado a falar e avançou em direção a uma plataforma alta, assim construída para que a multidão pudesse ouvi-lo. Dentre outras coisas, afirmou:

Temos uma forma de governo que em nada se sente inferior às leis dos nossos vizinhos, mas que, pelo contrário, é digna de ser imitada por eles. E chama-se democracia, não só porque é gerida segundo os interesses não de poucos, mas da maioria, e também porque, segundo as leis, no que respeita a disputas individuais, todos os cidadãos são iguais" (TUCÍDIDES, História da Guerra do Peloponeso, II, 37).

Afora a miríade de possíveis distinçóes entre a democracia ateniense e as democracias modernas, há algo de fundamental - posto que fundante - que precisa ser observado com rigor: se o que caracteriza os governos democráticos é o caráter coletivo das decisões, o respeito à soberania das decisóes coletivas deve ser assegurado de modo intransigente. Fora isso, qualquer ruptura, quando conduzida por um pequeno grupo à revelia da maioria, denuncia uma forma de traição ao princípio vigente. A esse movimento de ruptura, instaurado de forma violenta ou não, por grupos que já detém parte do poder e que dele se utilizam para ampliá-lo, dá-se comumente o nome de Golpe.

1 Professor do Departamento de História e do Programa de Pós-graduação em História (PPGH) da Universidade Federal Fluminense. Membro do Núcleo de Estudos de Representações e de Imagens da Antiguidade (NEREIDA/UFF) e colaborador do Laboratório de História Antiga (LHIA/UFRJ). 
A ideia de golpe passou a ser amplamente discutida no Brasil, dentro das muralhas das universidades e fora delas, a partir dos primeiros movimentos que conduziram à deposição de Dilma Rousseff. A presidenta, reeleita em 2014 pelo Partido dos Trabalhadores, foi afastada de seu cargo em 12 de maio de 2016 devido à instauração de um processo de impeachment. Seu mandato foi definitivamente cassado em 31 de agosto de 2016. A justificativa jurídicopolítica para o processo foram as chamadas "pedaladas fiscais". Diversas dúvidas, contudo, sobrepairam o processo por improbidade administrativa, inclusive em função de uma perícia realizada pelo Senado Federal e entregue à comissão do impeachment em 27 de junho de 2016, posto que o documento isentava a então presidenta afastada de participação nas "pedaladas fiscais".

Mas não apenas as dúvidas acerca das questóes fiscais entram na equação. A despeito das possíveis divergências técnicas que estariam na base do processo, as flagrantes questóes políticas envolvidas no impeachment reforçaram em muitos a convicção de que vivemos um golpe de Estado. As tensões estavam há tempos colocadas, mas o estopim do fato político foi claramente motivado pela forma com que o partido de Dilma Rousseff se posicionou a respeito da investigação, no Conselho de Ética da Câmara dos Deputados, em um processo por quebra de decoro parlamentar movido contra Eduardo Cunha (PMDB), então presidente da Câmara. Essa história foi corroborada pelo atual presidente em exercício, Michel Temer, em entrevista à TV Bandeirantes em maio deste ano: segundo ele, "se o PT tivesse votado nele naquela comissão de ética, é muito provável que a senhora presidente continuasse".

Mas se o processo foi alavancado por Eduardo Cunha, a participação ativa do então vice-presidente e de seu partido reforça a hipótese de golpe. Em dezembro de 2015, torna-se pública uma missiva que Michel Temer teria enviado à presidenta Dilma Rousseff fazendo críticas à forma com que era supostamente deslocado das decisões do governo, autoproclamando-se "vice decorativo". Adiante, também veio a público, na tarde de 11 de abril de 2016, um áudio em que o presidente ensaiava um discurso de posse. Temer alegou que, assim como a carta, se tratava de uma questão privada que se tornou conhecida a despeito de sua vontade; outrossim, e apesar da veracidade ou não dessa afirmação, o conteúdo é bastante sugestivo e indica o desejo do então vice-presidente de ver-se como chefe do Executivo. Esse princípio de publicidade acidental não se aplica, contudo, ao projeto Uma Ponte para o 
Futuro $^{2}$, lançado pelo partido do então vice-presidente da República em 29 de outubro de 2015. Após fazer um diagnóstico da crise econômica e uma série de críticas à condução de um governo do qual faziam parte de modo formal e efetivo, o programa do PMDB convida a nação [sic] para participar desse projeto formulado no interior do partido e que náo contava com o aval das urnas:

\begin{abstract}
Faremos esse programa em nome da paz, da harmonia e da esperança, que ainda resta entre nós. Obedecendo as instituições do Estado democrático, seguindo estritamente as leis e resguardando a ordem, sem a qual o progresso é impossível. O país precisa de todos os brasileiros. Nossa promessa é reconstituir um estado moderno, próspero, democrático e justo. Convidamos a nação a integrar-se a esse sonho de unidade (UMA PONTE PARA O FUTURO, 2015, p. 19)
\end{abstract}

Poderíamos também recordar a sessão deliberativa da Câmara dos Deputados do dia 17 de abril de 2016, onde os parlamentares presentes se dirigiam ao microfone para declarar o voto favorável ou contrário ao impeachment. Presidida pelo próprio Eduardo Cunha, que já era réu em um processo que veio a culminar com sua prisão, as declarações de voto raramente colocavam em questão o mérito do processo.

A todas essas questóes, poderiam ser adidas outras tantas que, desde então, vem tornando a ideia de golpe francamente presente em nosso cotidiano político, além de despertar o interesse intelectual de muitos que investigam esse e outros processos de ruptura, de tentativa de ruptura e de formas de resistência a ações que parecem contradizer, em prol dos interesses de poucos, o poder decisório da maioria. Os debates sobre a deposição de Dilma Rousseff continuarão por longos anos e serão objeto de acurada investigação por parte da historiografia. Em alguma medida, a historiografia não apenas tornará esses fatos objeto de rigorosa análise, mas também buscará entender esse momento sui generis da História do Brasil, seus efeitos já visíveis e tudo aquilo que ainda iremos experimentar ao longo dos anos. Vivemos uma inconteste crise política que revela o quanto a democracia é frágil e exige nossa atenta observação.

É precisamente por isso que a Hélade publica nessa edição o dossiê Golpes e formas de resistência na Antiguidade. Os artigos dialogam com o tema e mostram o quanto a experiência dos povos antigos é um locus importante

2 Disponível em http://pmdb.org.br/wp-content/uploads/2015/10/RELEASE-TEMER_A428.10.15-Online.pdf. Acesso em 02 de agosto de 2017. 
não apenas para a reflexão a respeito de nossos conflitos contemporâneos, mas também como espaço em que podemos contrapor experiências e identificar questóes que nos escapam na ausência de medidas de comparação. A quantidade significativa de artigos submetidos, encaminhados e aprovados pelos pareceristas ad hoc sinalizam o quanto os historiadores da Antiguidade estão sensíveis ao problema e mobilizados para torná-lo, no marco de nosso livre exercício de reflexão, uma questão a ser analisada por força das demandas do presente da vida social. 